DOI: $10.33608 / 0236-1477.2020 .01 .62-75$

УАК $82.091+821.162 .1: 82-92$

РишарА КУПІАУРА, Аоктор наук,

Університет ім. ААама Міцкевича, Познань (Польща),

Ul. Wieniawskiego, 1 Poznań, 61-712

e-mail: ryszardk@amu.edu.pl

ORCID: 0000-0003-4237-3828

\title{
ЗААНГАЖОВАНЕ ГОНЗО,
} НАСИАЬСТВО РЕПРЕЗЕНТАЦЇ̈

ТА МОЗАЇКА НАЦІОНААЬНИХ ФАНТАЗМІВ (ПРО «УКРАЇНСЬКУ ТРИАОГІЮ» ЗЕМОВITА ЩЕРЕКА) ${ }^{1}$

У статті проаналізовано три книжки Зємовіта Щерека: «Прийде Мордор інасзӥсть» (2013), «Татуювання з тризубом» (2015) та «Мікмор'я» (2017). Ці прачі, з огляду на присутність у них тем, пов'язаних зі східним сусідом Польщі, дослідник умовно поєднує в «українську трилогію». Висвітлено жанрові особливості доробку 3. Щерека, наслідки писання репортажів про країну з багатолітнім досвідом колоніальних стосунків із Польщеюо, погляд на українську ситуацію з понадрегіональної перспективи.

Ключові слова: Зємовіт Щерек, постколоніалізм, гонзо, імагологія, польська література, Украӥна.

Трилогія Юрія Андруховича — «Рекреації (1992), «Московіада» (1993) та «Перверзія» (1996) - відома нині не мише українському читачеві, свого часу порушила важливу проблему постколоніального стану України в перші роки незалежності. Ці тексти - вагоме слово в дискусії про не-

\footnotetext{
${ }^{1}$ Уперше надруковано польською мовою в часописі «Porównania». 2019. T. XXIV. № 1 (24). S. 55-67.
}

Ци т в ан н я: КупіАура РишарА. Заангажоване гонзо, насильство репрезентації та мозаїка національних фантазмів (про «українську трилогію» Зємовіта Щерека). Слово і Час. 2020. № 1 (710). С. 62-75. https://doi.org/10.33608/0236$1477.2020 .01 .62-75$ 
однозначність націонацьної емансипації, внутрішні трансгресії та стосунки з (пост)гегемоном. У «Перверзії» Аодатково йдеться про перспективу надрегіонального статусу країни та вписування ï в ширший, європейський контекст. Така інтерпретація дає змогу об'єднати й виокремити ці три романи із загального письменницького доробку Ю. Андруховича. Що більше, постмодерністична (часто означувана як карнавацьна) поетика згаАаних прозових творів даца підстави до розгляду їх саме у статусі трилогї.

Питання, які порушив український письменник, можуть послужити своєрідним ацгоритмом виявлення українських акцентів у репортажах Зємовіта Щерека. Упродовж останніх років його вважають одним із провідних польських письменників молодого покоління, котрий відомий також як активний учасник суспільних дискусій у Польщі. Уваги вартий той факт, що стиль самореалізації 3. Щерека як прозаїка нагадує українських

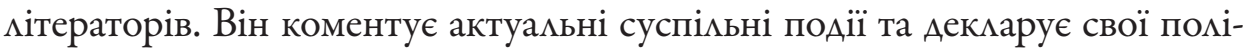
тичні погляди в медійному просторі, публікує фрагменти власних текстів і створює авторські меми. Така поведінка - важлива форма контакту $з$ публікою. Саме їі використовують чимало українських письменників різних поколінь (Артем Полежака, Юрій Винничук, Андрій Аюбка, Андрій Бондар, Григорій Семенчук, Олександр Ірванець, Світлана Поваляєва й ін.). Така самопрезентація практично не утвердилася в польському культурному середовищі. Навіть загострення політичних баталій і поглиблена поляризація суспільства нині не сприяли цьому. Важко сказати, чи на таку поведінку Щерека вплинув триваций контакт із українським творчим середовищем, чи це мише випадковий збіг обставин. ОАнак реакцію автора на суспільно-політичні зміни можемо трактувати як одну з багатьох віАповідей на запитання про витоки його емпатії до України. Українські мотиви, наявні в його текстах «Прийде Мордор і нас з їсть» (2013), «Татуювання з тризубом» (2015) і «Міжмор'я» (2017), стосуються кола проблем поАібного до прози Ю. Андруховича, а тому дають підстави скомпонувати їх у своєріАну «українську трилогію». Варто також зауважити, що З. Щерек - уважний читач «Московіади». У творах та в інтервю він зазначає, що романи Ю. Андруховича посідають не останнє місце в мектурі, яка формувала його світогмяА $[24,140-144 ; 12,129]$. Цим можна пояснити наявність у текстах молодого поцьського автора постколоніацьної аури, вмастивої українській мітературі 1990-х років. Хоча слід зазначити, що 3. Щерек працює в інших, ніж Ю. Андрухович, жанрах і застосовує відмінні від постмодерністичної поетики засоби мистецького вираження.

\section{Гонзо - заангажований жанр}

«Прийде Мордор і нас з'їсть - книжка, якою Зємовіт Щерек увійшов

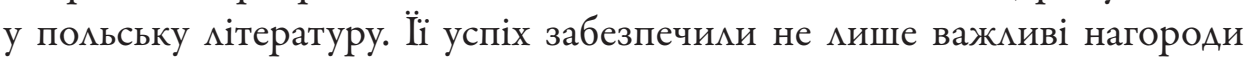


(Paszport «Polityki» 2013, номінація на престижну в Польщі мітературну премію «Nike» 2014), а й численні віАгуки критиків та цітературознавців. Із моменту видання 2013 р. аж донині не вщухає Аискусія щодо різноманітних проблем, порушених у ній, зокрема деконструкції національних міфів (як сучасних, так і тих, що стосуються давнього питання «кресів»), польських неоколоніальних симптомів, цюдини в посттотамітарній ситуації, віАносин центру і периферії, ацьтернативного туризму (a cаме, так званого poverty tourism - «бідного туризму»), а також цілий спектр жанрових питань, пов'язаних із упровадженням нової журналістики в польське середовище. У працях П. Чапиінського, Е. Рибіцької, I. Адамчевської, А. Каміна, Е. Жирек-Городиської, А. Янєц-Нийтрай, Й. Шилцовської, М. Цобель-Токарської, У. Пєчек, І. Борушковської, Р. Кабачія, А. Аевкової, Ю. Е. Аомбровської та інших досліджені й вичерпно описані практично всі ці аспекти. Тому немає потреби в їх повторній інтерпретаціі. Варто наголосити мише на двох випадках. Поперше, мітература із цієі теми дає суперечливі відповіді щодо жанрової класифікації книжки «Прийде Мордор і нас з’їсть». ІАеться не так про безрезультативні розмисли, на зразок чи маємо справу з романом дороги, чи, радше, з подорожньою літературою. Значно цікавішими видаються питання, якою мірою 3. Щерек реалізує постулати журналістики гонзо і яку функцію виконує автотематичний роздіц із такою ж назвою у книжці? І. ААамчевська, основуючись на широкій бібліографії за темою історії гонзо, визначає його як журнацістський стиль, прикметний крайнім суб'єктивізмом, вільною інтерпретацією фактів та мовною гіперболою. Автор - головний герой тексту, а пригоди авантюрного штибу 一 його фабулярна вісь. Участь героя, а подекуди й провокування ним самих подій розмиває кордони поміж суб'єктом і предметом оповіді $[6,187-188]$.

Такі ось принципи класичного гонзо. Його основоположником уважають американського письменника Гантера С. Томпсона, автора книжки «Страх і відраза в $\Lambda$ ас-Вегасі». «Прийде Мордор і нас з’їсть», безперечно, має з нею дещо спільне, утім не надто багато. У вищезгаданому автотематичному розділі 3. Щерек описує сутність гонзо, яке Ао певної міри на засадах travelling theory (теорії подорожі) - Аосягнумо Помьщі:

«Я почав професійно займатися тим, що гнав туфту <...>. Аостатньо було написати кілька текстів про Україну в тоні гонзо, як на мене посипамися замовлення. Епатував у тих текстах українським розпиздяйством і розпущеністю. Усе мусимо бути брудним, міцним і жорстоким. У цьому суть гонзо. У ньомує водяра, куриво, наркота й дівки, а також неодмінна наявність вульгаризмів» [23, 99].

Цей уривок цитує також I. ААамчевська, зауважуючи, що саме таке розуміння стилю гонзо втілене в тексті $[6,190]$. Подібна думка провокує 
певні сумніви, тим більше, що на підтвердження своєї позиції досліАниця обмежує особистість наратора до статусу «змостивого й неполіткоректного» $[6,190]$. Аумки I. ААамчевської суперечать також висновкам П. Чапмінського. 3 погляду останнього, найважиивіші пригоди, описані в книжці, не стосуються «хардкорних» вражень у барі чи в степу, вони засвідчують натомість зміну способу мислення [15]. Позиціонування твору як reportainment (тобто поєАнання репортажу та масової $і$ ітератури) $[6,196]$ могмо би пояснити його читацький успіх, але аж ніяк не посилену увагу дослідників. Не з'ясовує такий піАхіА і того, чому автор, залучаючи у книжку автотематичний розділ, поводиться як ілюзіоніст Кароля Іжиковського, котрий організовує останній виступ, щоб розкрити таємницю своєї майстерності $[7,69]$. 3 позиції маркетингу, це було 6 цілком невигіАно. В окремих інтерв'ю 3. Щерек утримується віА ототожнення свого роману з гонзо (це, звісна річ, не вирішацьне Аля дискусіі): «Прийде Мордор і нас з'їсть» не писався як гонзо. Я писав його радше як гонзо на тему гонзо» [цит. за: 13,78$]$. Перекониивішою видається пропозиція трактувати роман як можливість подивитись на гонзо з відстані, а також як спробу усвідомити необхідну ціну за привернення уваги сучасного читача $[27,230]$. У книжці розповідач Аукаш Пончинський згалує про раніше написані Аля інтернет-порталів статті в жанрі гонзо. У тексті ці статті не звучать, залишаючись остаточно в позиції in potentia. На прикцаді свого персонажа 3. Щерек показує, що гонзо, ви-

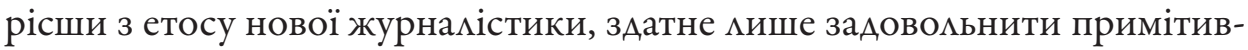
ні потреби хардкору або Schadenfreude (зморадства), що призводить до появи неоколоніацьних поглядів. Пончинський це цілком усвідомлює, а тому його історія набуває рис сповіді псевдорепортера.

Гонзо можна розглядати також із етичної позиції. Репортерське гонзо - це середовище, у якому стереотипи, чи точніше, мітературні образи, що активізують механізми стереотипізаціі, напрочуд симьні та примножуються без жодних перешкод із боку автора. Як наркотичне сп'яніння ілюзорно розширює межі Аюдської свідомості, так і підАавання спокусі гонзо ${ }^{1}$ начебто збільшує свободу журналіста, котрий остаточно випускає з поля зору героя свого невтіленого репортажу. Хардкор утрачає стафажне значення і стає центрацьною темою. Реалізація проєкту «водяра-куриво-наркота-дівки» по суті передбачає наявність постаті субалтерна, який у фіналі прибирає наслідки пиятики (цей епізод неминуче навоАить на думку сцену із приниженою покоївкою зі «Страху та віАрази...» Томпсона). Якщо ця пиятика ще й відбувається на території Іншого, то до всього додається мотив міжетнічної напруги. Тим часом «Мордор...»

\footnotetext{
${ }^{1}$ «Схимьність» до гонзо І. Адамчевська вцучно демаскує в репортажах Яцека Хуго-Бадера $[6,191]$.
} 
переповнений висловцюваннями українських постзалежних, які порушують це хардкорне блаженство:

«То я тобі розкажу, чому ви сюди їдете. Бо в інших краях із вас сміються. Там мають вас за тих, за кого нас маєте ви: за відстале задуп' я, з якого можна покпити. Супроти якого можна відчути себе кращим» $[23,37]$.

3. Щерек справді поводиться, ніби він ілюзіоніст, котрий демаскує вцасні трюки під час останньої вистави. У наступних книжках письменник не зрікається ні суб'єктивності, ні мовних гіпербол, однак відходить від гонзо, не використовує постаті автора/розповідача, а в місцях авантюрних пригод у текстах з'являються есеїстичні роздуми з приводу істоpiï регіону, про який ідеться.

«Прийде Мордор і нас з’ість» - це єдина із трьох аналізованих у цій статті книжок, яка на цей час перекладена українською мовою (Аив.: [4]). Окрім неї 2016 р. вийшов переклад «Сімки». СліА зазначити, що київське видання 2014 р. не здобуло активної читацької й дослідницької рецепції в Україні. Окрім рецензій А. Аевкової [2] та Р. Кабачія [1] на мітературних інтернет-порталах, годі шукати відгуків, які вписали би текст ${ }^{3}$ Щерека в ширший польсько-український контекст. Неувага до цієї книжки (але точно не їі замовчування) в українських дискусіях показова щонайменше з кількох причин. Можемо погодитися з тим, що поява перекладу твору 2014 р. збіглася з подіями Революції гіАності й початком російської агресії, унаслідок чого інтелектуальна еліта переймалася іншими проблемами. ОАнак і така причина видається симптоматичною, аАже Аһя польсько-українського Аіалогу після 1991 р. характерною виявилась відсутність часу на дискусію про важливі та складні А^я обох партнерів питання. Польсько-український діалог функціонує у тривалому стані «не зараз». Варто також зауважити, що польська тематика донеАавна була обмеженою в українських публічному й академічному дискурсах, а також у мітературній творчості та мистецьких практиках (символічного виміру в цьому випадку набуває відсутність польських акцентів у згаданій тримогії Ю. Андруховича), що цілком укцадається в контекст тих занедбань, які призвели до прикрих наслідків нині, коли цей діалог із тривалого «не зараз» перейшов у стадію «запізно». Отже, подані в тексті «Мордору...» варіанти можливих українських віАповідей залишаються мише авторською фантазією, чи, інакше кажучи, імітацією поглядів Іншого [3, 99]. Можна також сказати, що З. Щерек сам піддався впииву польського метастереотипу, який полягає в переконанні, що стосунки з польськістю посідають центрацьну позицію в українській колективній свідомості.

\section{Гра в піжмурки з постколоніаАьним критиком}

Анацізуючи ставлення Антонія Слонімського та Яцека Хуго-Бадера до Радянського Союзу й Росії на підставі їхніх подорожніх текстів, Ганна 
Госк зауважує: згадані автори провели більшу частину життя на польських територіях, повністю або частково залежних віА східної імперії, i цей факт вплинув на проблематику їхніх репортажів та на спосіб, у який вони були написані $[11,198]$. На такій же підставі могло би видатися, що історична залежність частини України віА Польщі та насичення тих теренів націонацьними польськими мітами ставить піА сумнів перспективу написання польських репортажів про Україну. У тому значенні, що Аавні польсько-українські стосунки, статус ексколонізатора й пов'язана 3 ним претензія на позицію експерта затьмарима б образ сучасної України в таких текстах. Утім тут є дещо актуацьніше. Аесятиліття перебування українців у скмаді СРСР, а також гомогенізаційні механізми репрезентації «радянського народу» поза Союзом призвели до того, що після 1991 р. незалежна Україна та ії мешканці виявились Аля поляків якоюсь мірою наново відкритим феноменом. Ао цього додацися ще й суспільні напруження, які регулярно розбурхують цю країну від початку XXI ст. Такі чинники стаци сприятливими дмя багатьох польських репортерів (Вєслава Романовського, Пйотра Погожельського, Пйотра Пєньонжка, 3бігнєва Парафіновича, Міхаца Потоцького, Гжегожа Шиманика, Юлії Візовської, Катажини Квятковської-Москацевич), котрі насичують свої тексти багатим фактологічним матеріалом і зосереджуються на витлумаченні суспільно-політичних реалій, приховуючи за викладом авторський голос. 3. Щерек обирає інший шлях - вихіА поза факти. Він дозволяє, аби так звані історичні передумови впливали на його розповіАь більшою мірою, ніж актуацьні політичні події. Збірка «Татуювання з тризубом», видана 2015 р., - це тексти про Україну напередодні й піА час Революції гіАності. Проте фабулярна вісь книжки, у якій поруч із репортажем з'являються також елементи історичного есе й навіть автобіографіï, аж ніяк не суспільні протести. Автор свідомо прагне зберегти статус зовнішнього спостерігача й коментатора, властивий подорожній мітературі, який небезпечно втягує в невдячну справу - переважання презентації над рефлексією. Усвідомлюючи, що жодна мандрівка не безневинна, пілігрим не має відмовлятися віА писання. 3. Щерек, почавши із себе, спочатку опублікував книжку «експіаційного» (віА мат. ехріatio - викуплення, спокута) характеру. Чи однак означає це ех officio, що автор може бути більш критичним щодо української ситуації? Або по-іншому: чи цей факт автоматично виключає патерналізм, що криється в критиці й пропонованих вирішеннях? Важко однозначно відповісти на ці запитання. Натомість доцільно обгрунтувати позицію, згіАно з якою в «Татуюванні з тризубом» письменник не екзотизує Україну, а обирає стратегію iii одомашнення. Тут можемо прочитати також спробу зменшити напругу залежності, яка виникає, власне, з того, що українські реалії описує й 
коментує польський репортер. Подібна стратегія базується на трьох заcaдax:

а) рауіоналізауї поведінки людей, про котрих пише автор (З. Щерек коментує дії своїх персонажів найчастіше за допомогою тверджень на зразок «загалом, це мене не здивувало», «я розумів їх», «я на їхньому місці зробив би те саме»);

б) пошуку аналогій у польській ситуащї (письменник неодноразово наголошує на тому, що Польща й Україна належать до спільної «постапокаціптичної» - як він сам їі характеризує - Аійсності, а тому чимамо їі наслідків можна знайти з обох боків кордону:

«Я часом їхав повз давні польські кладовища. Вони були абсолютно такі ж, як і давні німецькі в Нижній Сілезіі, Аюбуськім воєводстві чи на Помор'ї. Ну, може, хрести незграбніші, може, більше бетону, а менше каміння, може, написи не такі мереживні. А^е й там, і там - мертві прізвища на напівзруйнованих надгробках, що стирчать із-поміж диких хащ...» $[24,7])$;

в) упровадженні автобіографічних елементів. Вони мають свідчити про те, що самому авторові бцизький гнітючий досвіА життя в країні, яка навпомацки шукає самовираження й тягнеться до західних ідеалів, не завжАи сумісних із місцевою традицією. Мандруючи українськими містами, автор асоціює ї із рідними краями:

«Полтава довший період свого існування перебувала піА Росією, а тому справцяла враження типового російського імперіацьного міста. Низькі кам'яниці, обсаджені деревами вулиці. Тут гарно <...>, хоча краси тої не так уже й багато було. Заледве вигулькнула, і зникла. Я вже десь бачив таку архітектуру, але довго не міг згадати, де. Аж врешті збагнув, що Полтава нагадаца мені інше давнє губернське місто Росії - Радом (рідне місто 3. Щерека. - Р. К.) $\gg[24,181]$.

Зазначена стратегія криє в собі небезпеку візії вже не Мордору, як у випадку екстремальної екзотизації в гонзо, а просто Аругої Поцьщі. Ао «радикацьного» одомашнення України в «Татуюванні з тризубом» не доходить. Утім 3. Щерек показує, як український національний проєкт, століттями функціонуючи в умовах гнітючого колоніалізму й набуваючи в такий спосіб регресивних та екскмюзивних рис, намагається загоспоАарювати величезні географічні обшири, отримані 1991 р.: «Українська Аержава була не в змозі надати просторові власної форми, не вміла його модернізувати, а тому опанувала цей простір симвоцічно» $[24,6]$. Українськість у великих містах часто за інерцією асоціюється з рустикальними формами репрезентації, наприкцаА, через популярні кнайпи з традиційними українськими стравами, стилізовані піА інтер'єри сільських хат $[24,48]$. Зафарбовування пубцічного простору синьо-жовтими кольорами - це без сумніву спроба «зачакмувати» Аійсність та інфантильний 
метод акцентування на його належності до конкретної політичної спільноти. 3 іншого боку, взаємозв'язок простору й мюдини показує, що насправді адміністративні заходи мають свій ефект у процесі формування ідентичності. 3. Щерек визнає, що Аля нього становить певну загадку та обставина, чому українськість (у східних регіонах) не трансформувацася остаточно у варіант російськості, як, наприкцаА, сілезькість у варіант польськості, баварськість - німецькості, а провансацьськість - французькості [24, 40].

Репортер полемізує з Миколою Рябчуком, стверджуючи, що його не переконують тези українського пубціциста про великоруський колоніа-

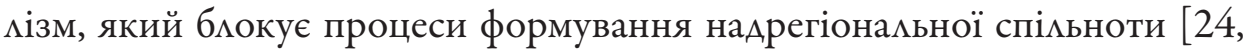
40]. Абстрагуючись віА самої дискусії, варто зазначити, що З. Щерек наАає перевагу індивідуацьній пам' яті й нетривалій історичній перспективі наА пам'яттю колективною, зміст якої зазнає непохитного впииву сьогоАення цієї спільноти [15, 349]. Саме тому в книжці «Прийде Мордор і нас з'ість» автор заперечує монолітність польської націонацьної спільноти поза кордонами батьківщини. У випадку Східної України його позицію найкраще ілюструють фрагменти, присвячені одному з міст Харківської області:

«Боже мій, що то було в Ізюмі. А нічого не було в Ізюмі. Ну, стоїть гарний, пофарбований на світло-блакитно собор, піА ним трохи бабусь у хустках, кілька дідусів із нігтями як апемьсинова шкірка. Той собор знаменита пам'ятка козацького бароко. Біля нього стояли якісь буди з бімої цегли, і було очевидно, що цьому світу не потрібна якась там святиня в козацькому бароко, мише ті буди з білої цегли.

Ті буди з білої цегли показували, чим насправді $є$ цей світ. Біла цегла розтягнута як Аовгий і широкий Ізюм, як довга й широка Слобожанщина, як довгі й широкі Україна та Росія, як довгою й широкою була Радянщина і як Аовгою й широкою $є$ Порадянщина» $[24,185]$.

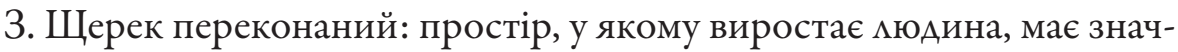
но більший вплив на їі формування, ніж колективна пам'ять із їі спекумятивним характером. Тому, незалежно віА того, чи письменник описує побут польських солдатів у Києві 1920 р., чи набіги козаків на Стамбул, чи позиції західноукраїнських військових на Донбасі, він передовсім намагається з'ясувати, яке враження на кожного з них справив чужий простір, котрий вони зіставцяють з індивідуацьними уявленнями, тобто пам'яттю про місця, де самі виростали.

Трубадурами колективної пам'яті в репортажах 3. Щерека стають персонажі, яких розповідач випадково зустрічає на вокзалах, на прикорАонних пунктах перепуску, у кнайпах, на автобусних зупинках тощо. Усі вони, Ао певної міри, репрезентанти постапокаліптичної історіософії. Ці ^юди виголошують патетичні тиради про давні золоті часи, про іс- 
торичну місію свого народу, і їхні думки своєрідно компенсують травму колоніацьного Аосвіду.

Воєнний конфмікт між Росією і Україною, здається, остаточно загальмував процес поглинання російськістю східної українськості. Нова ситуація стимулює до пошуку рішень, які зможуть задовольнити ідентичнісні потреби цієї частини України. 3. Щерек зауважує, що «Київ формує нову іАентичність, і хтозна, чи не буде вона однією з найоригінальніших ідентичностей у Європі» $[24,261]$.

\section{Україна в мозаӥці регіонамьних націонахьних фантазмів}

Видане 2017 р. «Міжмор'я» 3. Щерека - це, як влучно зауважив А. Ка-

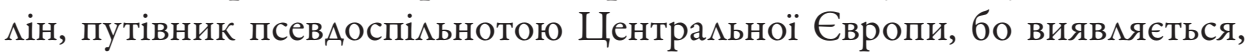
що вцастиво єАиний концепт, який поєАнує мозаїку народів у просторі цього віртуацьного Міжмор'я - це національна ідея, хоч насправді вона ix розділяє $[13,83]$. Уже саме порівняння марень про міць у стилі «Let's make Poland (Hungary, Slovakia, Macedonia etc.) great again» («Зробімо Польщу (Угорщину, Словаччину, Македонію тощо) великою знову») демаскує ілюзорність кожного з них, а також прихований наслідувацьний характер таких фантазій, уже не кажучи про те, що й саме це гасло - наслідувальне. Утеча віА Заходу, яку спостерігаємо в Центральній Європі, на думку 3. Щерека, нагадує «біг мемінгів» [22, 343], який завершиться або черговою перемогою західних іАей на цих землях, або їхнім поступовим потраплянням у сферу російського впливу.

Репортер типологізує й Аиференціює Центральну і СхіАну Європу найчастіше на підставі створеного в суспільстві простору, якому довіряє більше, ніж одкровенням, витягненим на поверхню з резервуарів колек-

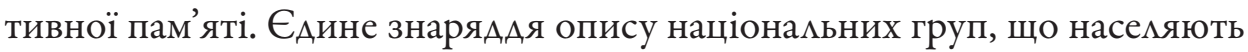
умовний регіон Міжмор'я, - це спостерігання за тим, як та чи та спільнота зможе співіснувати з наявним архітектурним середовищем. Ао того ж опорним пунктом таких спостережень зазвичай постає німецька моАель. Посттоталітарний період, описаний у текстах цієї книжки, автор часто іменує постапокаліпсисом. За 3. Щереком, це час, у якому «світ обмежив себе старінням і самозуживанням» $[23,12]$. Значну увагу письменник приділяє безформності й немічності в пошуках форми чи поверненні до неї. Першим переломним моментом постапокаліптичного періоду, по суті, став розпад соціалістичного бцоку. Утім це не означає, що раніше тут особливо Абали про форму. Архітектура, зведена ще в часи панування в цьому регіоні інших етносів, руйнується, але водночас вона набуває відмінних сенсів, на кшталт запущеного саду. З. Щерек зауважує, що подібно до того, як Аіс заростає мохом й омелою, так і будинки тут обростають будами, прибудовами, оргалітом, навіть шматками білбор- 
Аів, умонтованих замість стін і покрівемь $[23,12]$. Цей постапокаліптичний простір, що безперервно втрачає форму й не може набути нової, потребує віАповідної топоніміки. Щерек, вцасне, творить таку, уживаючи окреслення на зразок «Порадянщина», «Посовєтія», а територіям, патетично названим у часі Польської Народної Республіки Поверненими Землями (Ziemie Odzyskane), дає просту назву - Понімеччина. Іноді письменник апелює до екзонімів, що їх створили свого часу західні автори. У результаті цього прочитуємо такі топоніми як Руританія, Елбанія, Бордурія, Кракозія, Молванія, а також Мордор. Ацьтернативна топоніміка виконує у книжці не мише естетичну функцію. Перманентно номінуючи західні області України Галичиною, З. Щерек символічно звільняє їх від назви Галіція, за якою криється мітична полікультурність регіону, Ааючи йому в такий спосіб шанс на нову ідентичність. ОАнак спостерігаємо випадки, коли автор сам потрапляє в пастку ідеологічної боротьби в Україні. НаприклаА, щодо назви мешканців Аонбасу. Ігноруючи прикметник «донецькі» (у повсякденному мовленні він окреслює зазвичай мешканців не мише міста, а й цілого регіону), письменник надає перевагу етноніму «донбасити». Останній виявцяється неологізмом, який створили адепти нової історичної політики невизнаних квазідержав так званих АНР і $\Lambda$ НР. Їм же йшлося про увиразнення етнічної іншості мешканців регіону [5].

Щерека-репортера захопиюють мімінацьні простори. Рубежі, окраӥни, безкінечні кінці світів. Він намагається зафіксувати «банацьну й незбагненну порубіжну щоденність $>[22,245]$ і збагнути, як один світ перетікає в інший, як на останньому шматку землі певної держави проявцяється ї самобутність: чи то німецькість, чи то польськість, чи то Аитовськість, чи словацькість тощо. Показовим зразком є Богатиня, яку письменник іменує останнім бастіоном «Польбруку ${ }^{1}{ }^{\text {й шильдози }}{ }^{2}[22,245]$. Перетинаючи пішохідний кордон у Медиці (село Медика Перемишиьського повіту ПіАкарпатського воєводства. - Ред.), Щерек роздумує, який вигляд мала би ця місцевість, якби 1948 р. тодішній район Арогобицької області не приєАнали до Польщі за згодою СРСР: «Будинки були б трохи інші. Менше було би штукатурки-шуби, менше метамочерепиці, більше азбесту. Бруківка була б інша. <...> Бордюри були би пофарбовані в яскраво-білий колір» $[24,60]$. Іноді все ж наслідки могли би бути вагоміші. Відвідуючи на цвинтарі в прикордонній Һомні могилу Романа Мотичака - українського солАата, котрий загинув у боях піА Іловайськом, відАаценим віА ріАного села на тисячу кілометрів, - 3. Щерек визнає, що йому довго не давало спокою

\footnotetext{
${ }^{1}$ Виробник бруківки та бетонних дорожніх виробів, що працює на польському ринку з 1991 року. Найбімьш упізнавана марка на ринку бруківки в Польщі.

2 Термін, який використовують Аля опису рекцамного хаосу та засмічення рекцамою публічного простору.
} 
питання про те, ким був би сьогодні Роман Мотичак, якби 1951 р. комусь із тих, хто вирішував долю кордонів, зАригнулася рука й не Аійшло б до чергового обміну територіями між ПНР та СРСР? Можливо, сьогодні він був би емігрантом у Аондоні, а може, шукав би щастя у Варшаві? У будьякому випадку, Аонбас був би Аля нього дуже Аалеким.

Україна в «Міжмор”і» присутня мало. Причина цьому - не тільки присвята їй попередніх книжок автора. Звернімо увагу на те, що пробмеми, перед якими стоїть сучасна Україна, мають не так уже й багато спільного з розквітом консервативних національних ідей в інших державах Центральноєвропейського регіону. Ця країна, на відміну віА деяких сусідів, не втікає від Заходу. Тому вона не зовсім уписується в мозаїку сьогоднішнього «Міжмор'я», хоча, звісна річ, ії досвіА може бути нагадуванням аля всієї Центрально-Східної Європи про те, що загрозу воєнного конфмікту не варто трактувати мише гіпотетично.

Отже, «українська трилогія» Зємовіта Щерека - це багаторівневий погляд польського автора на українську сучасність. Також вона вносить важливий акцент як у польський українознавчий дискурс, так і у внутрішньопольські суспільні дискусії. Аля критиків і літературознавців обох країн творчість радомського прозаїка - це своєрідний викмик. Стиль його письма часто буває провокаційним, одначе не може затьмарити глибокої постколоніальної вразливості, притаманної цьому спостерігачеві. Читаючи окремі фрагменти репортажів, спершу виникає спокуса запідозрити автора в прихимьності до «бидлячого механізму, який спонукає трактувати поблажливо кожного провінціала» $[22,195]$ i мише у Аругому пориві усвідомлюємо, що акт звинувачення письменника $€$ одночасно цитатою з його ж книжки.

Переклала з польської Оксана Пухонська

\section{МITEPATУPA}

1. Кабачій P. Історії з країни Гірших. URL: http://litakcent.com/2014/09/24/istoriji-zkrajiny-hirshyh/ (16.01.2019).

2. Аевкова А. Шукачі східного гардкору, або Слова Петра про Павла... URL: https://zbruc. eu/node/26136 (16.01.2019).

3. Орехов B. “Ответная” митературная рецепция как объект имагологии // Аітературна компаративістика. Київ: ПЦ “Фоліант”, 2005. Вип. 1. С. 98-110.

4. Щерек 3. Прийде Мордор і нас з’їсть, або Таємна історія слов’ян. Київ: Темпора, 2014. $306 \mathrm{c}$.

5. AbibokJ. Polityka tożsamości samozwańczych republik na wschodzie Ukrainy. URL: https:// www.osw.waw.pl/pl/publikacje/komentarze-osw/2018-0606-/polityka-tozsamoscisamozwanczych-republik-na-wschodzie (16.01.2019).

6. Adamczewska I. "Wariacje na temat pewnego paktu. O dziennikarstwie gonzo" // Łódzkie Studia Literaturoznawcze. 2014. № 3 (1). S. 187-204.

7. Bakuta B. Oblicza autotematyzmu (autorefleksyjne tendencje w polskiej prozie po roku 1956). Poznań: WiS, 1991.136 s. 
8. Boruszkowska I., Pieczek U. "I opowiadać sobie wszystkie te ruskie hardkorowe historie..." ("Przyjdzie mordor i nas zje"). — URL: http://popmoderna.pl/\%E2\%80\%9Ei-opowiadacsobie-wszystkie-te-ruskie-hardkorowe-historie-przyjdzie-mordor-i-nas-zje/ (16.01.2019).

9. Cobel-Tokarska M. "Strasznie i pięknie" Ukraińskie podróże młodych Polaków // Sąsiedztwa III RP. Ukraina — zagadnienia społeczne. Red. M. Dębicki, J. Makaro. Wrocław: Gajt, 2015. S. $198-225$.

10. Dąbrowska J. E. Obraz państwa postapokaliptycznego w prozie Ziemowita Szczerka // Annales Universitatis Mariae Curie-Skłodowska. Sectio FF, Philologiae. 2016. № 34 (2). S. 187-199.

11. Gosk $H$. Wychodzenie z "cienia imperium”. Wątki postzależnościowe w literaturze polskiej XX i XXI wieku. Kraków: Universitas, 2015.264 s.

12. Janiec-Nyitrai A. Zobaczyć na nowo. Podróże literackie Andrzeja Stasiuka, Krzysztofa Vargi i Ziemowita Szczerka. Budapest: Budapest Főváros XIII. Kerületi Lengyel Nemzetiségi Önkormányzat, 2018.264 s.

13. Kalin A. Polska szkoła zmyślania — literacki reportaż podróżniczy. Podróże z Mordoru do Międzymorza Ziemowita Szczerka // Forum poetyki. 2018. № 11-12. S. 64-85.

14. Kwiatkowska-Moskalewicz K. Zabić smoka. Ukraińskie rewolucje. Wołowiec: Czarne, 2016. $208 \mathrm{~s}$.

15. Literatura 2013. Nominowany Ziemowit Szczerek. (2013, December 3). URL: https://www. polityka.pl/tygodnikpolityka/kultura/paszporty/1563357,1,literatura-2013-nominowanyziemowit-szczerek.read (16.01.2019).

16. Modi memorandi: Leksykon kultury pamięci. Red. M. Saryusz-Wolska, R. Traba. Warszawa: Wydawnictwo Naukowe Scholar, 2014. 592 c.

17. Parafianowicz Z., Potocki M. Wilki żyją poza prawem. Jak Janukowycz przegrał Ukrainę. Wołowiec: Czarne, 2016. $424 \mathrm{~s}$.

18. Pieniażek P. Wojna, która nas zmieniła. Warszawa: Wydawnictwo Krytyki Politycznej, 2017. $240 \mathrm{~s}$.

19. Pogorzelski P. Barszcz ukraiński. Gliwice: Helion, 2014. 352 s.

20. Romanowski W. Przystanek wolność. Kraków: Wydawnictwo literackie, 2007. $194 \mathrm{~s}$.

21. Rybicka E. Geopoetyka. Przestrzeń i miejsce we współczesnych teoriach i praktykach literackich. Kraków: Universitas, 2014. 484 s.

22. Szczerek Z. Międzymorze. Warszawa: Agora SA, Czarne, 2017.344 s.

23. Szczerek Z. Przyjdzie Mordor i nas zje, czyli tajna historia Słowian. Kraków: Korporacja Ha!art, 2013. $220 \mathrm{~s}$.

24. Szczerek Z. Tatuaż z tryzubem. Wołowiec: Czarne, 2015.328 c.

25. Szydtowska J. O pożytkach z podglądania marginesu, czyli po co centrum peryferie. Egzotyzacja świata w prozie reportażowej Ziemowita Szczerka (Przyjdzie Mordor i nas zje, czyli tajna historia Słowian)" // Centr a-peryferie w literaturze polskiej XX i XXI wieku. Red. W. Browarny, D. Lisak-Gębala, E. Rybicka. Kraków: Universitas, 2015. S. 375-387.

26. Szymanik G., Wizowska, J. Po północy w Doniecku. Warszawa: Agora SA, 2016. 200 s.

27. Żyrek-Horodyska E. Od amerykańskiego snu Thompsona po ukraiński Mordor Szczerka. Estetyzacja świata w duchu gonzo // Konteksty kultury. 2017. T. 14. Z. 2. S. 217-232.

Отримано 29 грудня 2019 р.

\section{REFERENCES}

1. Kabachii, R. (2014, September 24) Istorii z krainy Hirshykh. - URL: http://litakcent. com/2014/09/24/istoriji-z-krajiny-hirshyh/ (16.01.2019). [in Ukrainian]

2. Levkova, A. (2014, August 28) Shukachi skhidnoho hardkoru, abo Slova Petra pro Pavla.... URL: https://zbruc.eu/node/26136 (16.01.2019). [in Ukrainian]

3. Orekhov, V. (2005) "Otvetnaya" literaturnaya retseptsiya kak obyekt imagologii. Literaturna komparativistika, 1, pp. 98-110. [in Russian]

4. Szczerek, Z. (2014) Pryide Mordor inas zist, abo Taiemna istoriia slovian. Kyiv: Tempora. [in Ukrainian] 
5. Abibok, J. (2018, June 6) Polityka tożsamości samozwańczych republik na wschodzie Ukrainy. - URL: https://www.osw.waw.pl/pl/publikacje/komentarze-osw/2018-0606-/ polityka-tozsamosci-samozwanczych-republik-na-wschodzie (16.01.2019). [in Polish]

6. Adamczewska, I. (2014) "Wariacje na temat pewnego paktu. O dziennikarstwie gonzo" Eódzkie Studia Literaturoznawcze,. 3 (1), pp. 187-204. [in Polish]

7. Bakuła, B. (1991) Oblicza autotematyzmu (autorefleksyjne tendencje w polskiej prozie po roku 1956). Poznań: WiS. [in Polish]

8. Boruszkowska, I. \& Pieczek, U. (2013, July15) "I opowiadać sobie wszystkie te ruskie hardkorowe historie..." ("Przyjdzie mordor i nas zje"). - URL: http://popmoderna. $\mathrm{pl} / \% \mathrm{E} 2 \% 80 \% 9 \mathrm{Ei}$-opowiadac-sobie-wszystkie-te-ruskie-hardkorowe-historie-przyjdziemordor-i-nas-zje/ (16.01.2019). [in Polish]

9. Cobel-Tokarska, M. (2015) "Strasznie i pięknie" Ukraińskie podróże młodych Polaków In Dębicki, M. \& Makaro, J. (Eds.). Sąsiedztwa III RP. Ukraina — zagadnienia społeczne, pp. 198-225. Wrocław: Gajt. [in Polish]

10. Dąbrowska, J. E. (2016) Obraz państwa postapokaliptycznego w prozie Ziemowita Szczerka Annales Universitatis Mariae Curie-Sktodowska. Sectio FF, Philologiae, 34 (2), 187-199.

11. Gosk, H. (2015) Wychodzenie z "cienia imperium". Watki postzależnościowe w literaturze polskiej XX i XXI wieku. Kraków: Universitas. [in Polish]

12. Janiec-Nyitrai, A. (2018) Zobaczyć na nowo. Podróże literackie Andrzeja Stasiuka, Krzysztofa Vargi i Ziemowita Szczerka. Budapest: Budapest Főváros XIII. Kerületi Lengyel Nemzetiségi Önkormányzat. [in Polish]

13. Kalin, A. (2018) Polska szkoła zmyślania - literacki reportaż podróżniczy. Podróże z Mordoru do Międzymorza Ziemowita Szczerka Forum poetyki, 11-12, 64-85. [in Polish]

14. Kwiatkowska-Moskalewicz, K. (2016) Zabićsmoka. Ukraińskie rewolucje. Wołowiec: Czarne. [in Polish]

15. Literatura 2013. Nominowany Ziemowit Szczerek. (2013, December 3). — URL: https:// www.polityka.pl/tygodnikpolityka/kultura/paszporty/1563357,1, literatura-2013nominowany-ziemowit-szczerek.read (16.01.2019). [in Polish]

16. Saryusz-Wolska, M. \& Traba, R. (Eds.). Modi memorandi: Leksykon kultury pamięci. (2014) Warszawa: Wydawnictwo Naukowe Scholar. [in Polish]

17. Parafianowicz, Z. \& Potocki, M. (2016) Wilki żyja poza prawem. Jak Janukowycz przegrat Ukraine. Wołowiec: Czarne. [in Polish]

18. Pieniążek, P. (2017) Wojna, która nas zmienita. Warszawa: Wydawnictwo Krytyki Politycznej. [in Polish]

19. Pogorzelski, P. (2014) Barszcz ukraiński. Gliwice: Helion. [in Polish]

20. Romanowski, W. (2007) Przystanek wolność. Kraków: Wydawnictwo literackie. [in Polish]

21. Rybicka, E. (2014) Geopoetyka. Przestrzeń i miejsce we wspótczesnych teoriach i praktykach literackich. Kraków: Universitas. [in Polish]

22. Szczerek, Z. (2017) Międzymorze. Warszawa: Agora SA, Czarne. [in Polish]

23. Szczerek, Z. (2013) Przyjdzie Mordor i nas zje, czyli tajna historia Stowian. Kraków: Korporacja Ha!art. [in Polish]

24. Szczerek, Z. (2015) Tatuaż ztryzubem. Wołowiec: Czarne. [in Polish]

25. Szydłowska, J. (2015) O pożytkach z podglądania marginesu, czyli po co centrum peryferie. Egzotyzacja świata w prozie reportażowej Ziemowita Szczerka (Przyjdzie Mordor i nas zje, czyli tajna historia Słowian) In Browarny, W., Lisak-Gębala, D.\& Rybicka, E. (Eds.) Centr a-peryferie w literaturze polskiej XX i XXI wieku, pp. 375-387. Kraków: Universitas. [in Polish]

26. Szymanik, G. \& Wizowska, J. (2016) Po pótnocy w Doniecku. Warszawa: Agora SA. [in Polish]

27. Żyrek-Horodyska, E. (2017) Od amerykańskiego snu Thompsona po ukraiński Mordor Szczerka. Estetyzacja świata w duchu gonzo Konteksty kultury, 14, 2, 217-232. [in Polish]

Received 29 December 2019 


\section{Ryszard Kupidura, $\mathrm{PhD}$}

Adam Mickiewicz University in Poznań

1 Wieniawskiego str., Poznań, 61-712, Poland

e-mail: ryszardk@amu.edu.pl

ORCID: 0000-0003-4237-3828

\section{ENTANGLED GONZO, VIOLENCE OF REPRESENTATION, AND MOSAIC OF NATIONAL FANTASIES, OR ABOUT "UKRAINIAN TRILOGY" BY ZIEMOWIT SZCZEREK}

The aim of this paper is an analysis of the three books by the Polish journalist, writer, and traveler Ziemowit Szczerek: "Mordor will come and eat us" (2013), "Tattoo with Trident" (2015), and "Intermarium" (2017). Due to the presence of themes related to Poland's eastern neighbor the author of the paper conventionally groups them as "Ukrainian trilogy". In particular, the paper focuses on the genealogical status of Szczerek's work, highlights the consequences of writing books about the country with a long and complex history of colonial relations with Poland, and considers an attempt to look at the Ukrainian situation from a supra-regional perspective.

In the case of "Mordor..." the author of the present paper is interested in the still dubious genealogical status of the novel, which, apart from its purely formal role, is also important for determining the writer's position in relation to the described country. In the collection of reportages "Tattoo with Trident", the writer gives up the easy strategy of exoticizing Ukraine and proposes his own strategy of domestication, which consists of three principles: a) rationalizing the attitudes of the people described; b) looking for analogies between the Polish and Ukrainian situation; c) introducing autobiographical threads. "Intermarium" is a literary guide to the countries that make up the pseudo-community, because they have a national idea that separates them. The comparison of dreams concerning power in the style of "Let's make Poland (Hungary, Slovakia, Macedonia, etc.) great again" reveals the illusiveness of such thinking and the hidden imitative character of these fantasies, just like the slogan itself. Szczerek claims that escape from the West taking place in Central Europe resembles a "run of lemmings", which will end with either a renewed victory of Western ideas in these lands or their gradual falling into the Russian sphere of influence.

Keywords: Ziemowit Szczerek, postcolonialism, gonzo, imagology, Polish literature, Ukraine. 